\title{
THE ANTITRUST ASPECTS OF MERCHANDISING MODERN MUSIC: THE ASCAP CONSENT JUDGMENT OF I950
}

\author{
Sigmund Timberg*
}

\section{INTRODUCTION}

For long centuries, the "music makers" and "dreamers of dreams" of Arthur O'Shaughnessy's memorable poem sustained their material existence by direct appeal to the largesse of sympathetic tribal chieftains or comfortably circumstanced patrons. In more modern times, they have aspired to throw off the patron's yoke and establish a more direct relationship with the literate reading public; and so, copyright evolved as the property institution designed to give them their due material rewards. In the last half-century, however, the highly organized media of mass communicationmotion pictures, radio, and more recently television-have supplanted the music sheet and the printed book as the song writer's major links with his public and have multiplied that public tremendously. ${ }^{1}$ Accordingly, the song writers banded together in business associations with their publishers, who had been their earlier commercial bridge to a smaller and more dispersed audience. These associations were formed for the commercial exploitation of that peculiar copyright privilege which covers public performance to a mass audience-the so-called performing or performance right-and are called performing right societies. The dominant performing rights society in the United States is the American Society of Composers, Authors and Publishers, colloquially known as ASCAP.

Once organized on a broad commercial scale for profit, even the aesthetic pursuit of dreams, music, and other evidences of the free spirit may engender commercial repressions inconsistent with our basic antitrust philosophy of free trade and fair competition. This article will deal with a fertile source of alleged monopoly and trade restraint in the mass entertainment field-ASCAP's entanglements with the Sherman Act. A more comprehensive approach would entail an historical and tainment and mass edification; accordingly, this article will focus on a single legal economic treatise covering at least six major industries in the domain of mass enterdocument- the Amended Consent Judgment entered against ASCAP in $1950^{2}$-and

\footnotetext{
- Member of the New York bar; former Chief, Judgment and Enforcement Section, Antitrust Division, Department of Justice and Secretary, United Nations Ad Foc Committee on Restrictive Business Practices.

${ }^{1}$ For indications of the drastic extent to which radio and sound pictures supplanted phonograph records and sheet music as the dominant source of revenue for composers, see Gitlin, Radio Infringement of Music Copyright, Copyright Law Symposium (The Nathan Burkan Memorial Competition) 6r, at 62 (1939); Cohen, State Regulation of Musical Copyright, id. at 91, 115, 116; Henderson, The Law of Copyright, Especially Musical, id. at $125,162$.

${ }^{2}$ Commerce Clearing House, Inc., I950-195I Trade Cases ff 62,595. The author's role as governmental representative in the framing of this judgment gives his remarks no authority whatsocver. The
} 
the welter of considerations that gave that document its present, judicially blessed contours. The author hopes to set forth the legal, economic, and social problems created when artistic endeavor becomes industrially organized for profit and sells its artifacts in the commercial market place, and to present some insights into that socially creative and legally artistic process that has emerged as an apt instrument for settling antitrust controversy-the modern consent judgment.

By way of setting the stage, it will be necessary to describe briefly, first, the complex but circumscribed legal right that is ASCAP's sole stock in trade-the minor or non-dramatic performing right in a musical composition; and, second, the economic nature of the entertainment business package marketed by ASCAP. Only then will the stage be set for three large acts in this industrial problem-play, describing the three main commercial tugs of war that have kept ASCAP in continuous antitrust turmoil and anxiety since its organization in rgr4. These three acts may be entitled, respectively:

I. The Motion Picture Industry Versus ASCAP

II. The Radio and Telecasting Industry Versus ASCAP

III. ASCAP Versus ASCAP

A. ASCAP's Legal Stock in Trade-The Minor Performing Right

Unlike the patent grant, which has from its inception conferred on the patentee all-pervasive statutory rights to make, use, and vend an invention, copyright in this country is a generic (and essentially fictitious) name for a bundle of narrowly defined rights, specifically enumerated in the governing federal copyright statute and even further subdivided in commercial practice. ASCAP is a licensing organization confined to the licensing of, and collection of royalties for, a single one of these sub-varieties of copyright-the minor performing or performance right. As ASCAP's name partly implies, the minor performing rights transferred to ASCAP relate only to copyrighted musical compositions. The minor performing rights under ASCAP's control are the rights publicly to perform copyrighted musical compositions for profit, but in a non-dramatic manner.

This right to perform copyrighted music publicly for profit is completely separate from the copyright in the printed sheet music. ${ }^{3}$ It has nothing in common with the recording right under which the phonograph industry is licensed to make records. ${ }^{4}$ It must be distinguished from the so-called synchronization right, i.e., the motion picture producer's right to make a music sound-track for a sound film; ${ }^{5}$ this latter

District Judge who entered the judgment, in conformity with the prevailing practice, gave no indication as to the legality or illegality of ASCAP's past organization or contemplated reorganization, or of its old or new practices. The interpretation of the document, at any moment of time, is for the current officers of the Department of Justice and the then legal representatives of ASCAP and, in the event of their disagreement, for the Federal District Court for the Southern District of New York.

${ }^{3}$ Interstate Hotel Co. of Nebraska v. Remick Music Corp., 157 F. 2d 744 (8th Cir. 1946), cert. denied, 329 U. S. 809 (1946).

'Irving Berlin v. Daigle, 3 I F. 2d 832 (5th Cir. 1929).

${ }^{5}$ Famous Music Corp. v. Melz, 28 F. Supp. 767 (W. D. La. I939); Jerome v. Twentieth Century Fox Film Corp., 67 F. Supp. 736 (S. D. N. Y. 1946) (also discusses right of mechanical reproduction for phonograph records), aff'd per curiam, 165 F. 2d $784^{\prime \prime}$ (2d Cir. 1948). 
right is licensed on an individual basis through a mechanism other than ASCAP, but the right to play off the sound-recorded film in a theatre is a performing right licensed through ASCAP. And, however murky the dividing line occasionally becomes, the minor performing right in a musical composition must be disassociated from the right to use the same composition in a dramatic performance, the so-called major performing right. ${ }^{6}$ All these other copyright privileges are licensed to users on an individual basis; only the minor performing right is licensed on a collective, pooled basis, as part of a property conglomerate-the bundle of minor performing rights in musical compositions assigned to ASCAP which is popularly referred to as the ASCAP repertory.

The assignment to ASCAP of minor performing rights in musical compositions has created legal and practical complexities not present in the case of other varieties of copyright. As a general rule, the music publisher has claimed the legal title in, and general control over the commercial management of, musical copyrights. Such protections as the composers or authors have been able to establish for themselves have been of a contractual rather than a proprietary nature; the alleged withholdings of composer-author revenues and other over-reachings of the unscrupulous publisher have been kept in check only by such things as the gradual evolution of a protective standard-form contract ${ }^{7}$ and occasional court pronouncements as to the trusteeship role held by the publisher in relation to the composer and author. ${ }^{8}$ In the case of the performing rights assigned to ASCAP, however, the composers and authors become equal partners with the publishers in the commercial administration of their artistic creations. They share simultaneously with (not derivatively from) the publishers in an equal apportionment of the revenues resulting from a joint commercial venture.

Composers and authors would doubtless therefore consider it a serious impairment of their economic status if they were deprived of their direct role in the control of license revenues. Furthermore, any attempted reassignment of performing rights by ASCAP to its members would probably precipitate claims by its publisher-members that they possessed full legal title to the performing rights in compositions falling within their respective catalogues; contentions by composer and author members that they had a joint, half, or co-ownership interest in the legal fee; and a rash of lawsuits calling into play the different equities prevailing between individual publishers and the composers and authors represented in their catalogues.

\footnotetext{
'In the blanket network television license agreement between ASCAP and its licensecs, a dramatic performance is defined to "mean a performance of a musical composition on a television program in which there is a definite plot depicted by action and where the performance of the musical composition is woven into and carries forward the plot and its accompanying action. The use of dialogue to establish a mere program format or the use of any non-dramatic device merely to introduce a performance of a composition shall not be deemed to make such performance dramatic."

"Klein, Protective Societies for Authors and Creators, Copyright Problems Analyzed ig (Commerce Clearing House, I953).

${ }^{8}$ Broadcast Music v. Taylor, 55 N. Y. Supp. $2 d 94$ (Sup. Ct. N. Y. Co. 1945); Cacsar v. Ziegfeld, 223 App. Div. 86, 226 N. Y. Supp. 510 (Ist Dep't 1928).
} 


\section{B. ASCAP's Business Bundle-Its Repertory}

ASCAP licenses only the pooled aggregate of the performing rights assigned to it by its members, i.e., its entire repertory. It licenses that aggregate for specific industrial uses-radio broadcast, dance hall or symphony concert-but its licenses always convey a blanket authorization to the licensee to use its entire repertory; it never licenses the right to perform individual pieces, or individual publisher's catalogues, or any part of its total repertory. Such "per piece" licenses would be commercially impracticable and would also jeopardize a sine qua non of ASCAP's existence-the avoidance of discrimination among its members.

The performing rights pool thus licensed by ASCAP encompasses the predominant bulk-estimated at times to be from 85 to 90 per cent ${ }^{3}$-of the popular and classical music of this country that has not passed into the public domain. To this must be added the copyrighted music of some 40,000 foreign composers and authors, whose respective national performing societies have authorized ASCAP to license their compositions for performance in the United States. ${ }^{10}$ The ASCAP repertory is estimated to contain a million compositions.

ASCAP seeks to justify this factual monopoly by the pragmatic plea of commercial necessity. The users of its music, scattered throughout a large country, working round the clock and responsive to suddenly inspired bursts of popular taste and sentiment, must have the immediate right to use any number in ASCAP's million-fold repertory. The disk-jockey's itchy fingers and the bandleader's restive baton, it is said, cannot wait for contracts to be drawn with ASCAP's individual publisher members, much less for the formal acquiescence of a characteristically unavailable composer or author, or-heaven forfend the legal ramifications!-the manifold unascertainable and unlocatable heirs, assigns, or other legal representatives of the composer and author. A blanket license covering ASCAP's total repertory is the price of avoiding industrial palsy in the entertainment world, says ASCAP, and thus far no important commercial user of ASCAP's music has contradicted this assertion for any length of time.

ASCAP's collection of a fee on its entire repertory (although individual users use only a very minute portion of this repertory) may find some legal support in the increasing tendency of the courts to allow a patentee licensing a block of patents to collect royalties on the basis of the licensee's total production, regardless of the number of patents specifically employed in the licensee's operations. ${ }^{11}$ It should

\footnotetext{
- Sce Justice Black, dissenting, in Gibbs v. Buck, 307 U. S. 66, at 81 (1939); Buck v. Swanson, 33 F. Supp. 377,386 (D. Nebr. I939); Buck v. Gallagher, 36 F. Supp. 405 (W. D. Wash. I940).

${ }^{10}$ ASCAP's exclusive arrangements for the catalogues of foreign performing rights societies was the basis of a Sherman Act complaint charging ASCAP with being a member of an illegal international cartel. This proceeding was terminated by a separate consent judgment, entered concurrently with the domestic judgment with which this article is concerned. See Commerce Clearing House, Inc. 1950i951 Trade Cases $\$ 62,594$.

11 Automatic Radio Manufacturing Co. v. Hazletine Research, 339 U. S. 827 (I950); Hazletine Research, Inc. v. Admiral Corp., 87 F. Supp. 72 (N. D. Ill. 1949); H-P-M Development Corp. v. WatsonStillman Co., 7 I F. Supp. 906 (D. N. J. 1947); Ohio Citizens Trust Co. v. Air-way Electric Appliance Corp., 56 F. Supp. Io10 (N. D. Ohio 1944).
} 
be borne in mind, however, that the cases upholding this policy of administrative convenience involved no charges of monopolistic power or antitrust conspiracy such as feature the ASCAP landscape. ${ }^{12}$

ASCAP's pragmatic monopoly is grounded by it on a further considerationthe fact that a licensee of its repertory obtains, together with his license, the practical assurance that he is not infringing a musical copyright. This protection-remotely analogous to title insurance-is, of course, qualified by the limited extent to which ASCAP is not a roo per cent monopoly and performing rights in copyrighted musical compositions subsist outside the ASCAP repertory. But the possessor of a blanket ASCAP license cannot be subjected to the conflicting claims of rival copyright owners (if they are members of ASCAP) for compensation for playing a particular piece of music. This consideration bears some resemblance to one of the major justifications for patent pools, to wit, that they are necessary in order to avoid patent interferences and to keep patent users from being caught in the legal crossfire of conflicting patent holders. ${ }^{13}$ Here again, it should be pointed out that patent pools which create trade restraints are illegal.

ASCAP's third main justification-which has been sympathetically viewed by some courts ${ }^{14}$-is the helplessness of its individual members to enforce their rights. The individual composer, author, or publisher would, it has been felt, be utterly powerless to detect infringements of his performance rights in the thousands of places where his music might be publicly performed for profit, and therefore has need of a nation-wide policing organization like ASCAP. Furthermore, the financial cost of copyright infringement litigation is frequently prohibitive if borne by individuals alone.

ASCAP's relations with the users of its music comprehend only the licensing of its repertory, the collection of license fees, the detection of copyright infringement, and the enforcement of legal proceedings to redress infringment. These functions have led to its being described as a clearing house, copyright pool, joint collection agency, and, very recently, "banking institution."15 From its members it receives performance rights and to its members it disburses revenues, after deducting its costs of administration.

With this much of a commercial and legal prologue, we come now to ASCAP's most recent and hazardous joust with the Sherman Act-its imbroglio with the motion picture industry.

\footnotetext{
${ }^{12}$ See Watson v Buck, $33_{3}$ U. S. 387 (194I); cases cited supra note 9; cf. United States v. General Instrument Corp., 87 F. Supp. 157 (D. N. J. 1947) (patent pool).

${ }^{13}$ Standard Oil Co. (Indiana) v. United States, 283 U. S. 163 (193I); Sbicca-Del-Mac v. Milius Shoe Co., 145 F. 2d 389 (8th Cir. r944).

${ }^{21}$ Cf. Buck v. Gibbs, 34 F. Supp. 5 10 (N. D. Fla. 1940); Alfred Bell \& Co. v. Catalda Fine Arts, I9I F. 2d 99 (2d Cir. I95I).

${ }^{15}$ Propper v. Clark, 337 U. S. 472 (1949).
} 


\section{The Motion Picture Industry Versus ASCAP}

\section{A. Legal Clouds}

On July 18, x948 Federal District Judge Leibell handed down his memorable opinion in the Alden-Rochelle case ${ }^{16}$ declaring ASCAP to be involved in an illegal monopoly and illegal restraint of trade under sections I and 2 of the Sherman Act. The Alden-Rochelle case was a private treble damage action for violation of the Sherman Act, brought by a closely affiliated group of some ${ }^{16} 4$ motion picture theatre exhibitors. A clear understanding of the court's legal rationale requires, in addition to facts already stated, a recapitulation of some of the other salient facts of record as found by the court.

There were in the United States some I7,000 motion picture theatre exhibitors licensed to perform ASCAP's repertory, and some 13,00o hotels and places of entertainment using ASCAP's music. ASCAP had, among its publisher-members, music publishing houses which were either direct subsidiaries of motion picture producers or had strong contractual ties with such producers; 37 per cent of the ASCAP revenues available for distribution to the publishers (which were 50 per cent of total ASCAP net revenues) went to such movie-producer-dominated publishers. The synchronization (or recording) rights on the sound films played in the theatres were licensed to motion picture producers, on an individual basis, by individual publishers at the time the film was being produced. Motion picture producers, in dealing with non-ASCAP compositions, acquired the performance rights themselves; in the case of ASCAP compositions, on the other hand, the theatre exhibitors had to pay the extra cost of acquiring the performing right.

ASCAP, said the court, had the power to raise prices and exclude competitors when it desired to do so. Therefore, following the rule of the Alcoa ${ }^{17}$ and American Tobacco $^{18}$ cases, it was an illegal monopoly under section 2 of the Sherman Act. ${ }^{18}$ The court declined to award damages, because there was no proof that ASCAP, in the royalties it had demanded, had unreasonably exercised its rights. Yet, it was the power to fix prices, and not the reasonableness of the exercise of that power, that was determinative of ASCAP's liability under the Sherman Act.

The transfer of non-dramatic (minor) performing rights from the ASCAP members to ASCAP was held to be a restraint of trade under section I of the Sherman Act. So was the ASCAP rule barring its members from assigning performing rights to motion picture producers at the time the film was being produced. This restraint was found to have been supplemented by the provision in the contract between motion picture distributors and exhibitors which limited the public exhibition of the

\footnotetext{
${ }^{10}$ Alden-Rochelle v. ASCAP, 80 F. Supp. 900 (S. D. N. Y. 1948).

${ }^{17}$ United States v. Aluminum Co. of America, I48 F. $2 \mathrm{~d}{ }_{416}$ (2d Cir. 1945) (opinion by Circuit Judge Learned Hand).

${ }_{18}$ American Tobacco Co. v. United States, 328 U. S. 78I (I946).

${ }^{10}$ Earlier cases holding ASCAP to be an illegal monopoly had also relied on United States $v$. Socony Vacuum Oil Co., 310 U. S. I50 (x940), see note 9, supra.
} 
rented film (films are rented, not sold, to exhibitors) to exhibitors with ASCAP licenses. All these restraints were the subject of injunctive relief in Judge Leibell's original judgment in this case (which, for reasons set forth later, was subsequently superseded).

Finally, the court declared that there existed an unlawful combination in restraint of trade between motion picture producers and ASCAP members, involving an illicit combination of the copyrights in motion pictures and in musical compositions, respectively. This combination was exercised in such a way as unlawfully to extend the monopoly of both copyright privileges, in a manner reminiscent of the "blockbooking" of copyrighted films denounced in the Paramount case ${ }^{20}$ and of the patent cross-licensing found illegal in the Line Materials case. ${ }^{21}$ The antitrust questions tendered by this legal conclusion have since been the subject of a separate private treble damage action filed against ASCAP publishing houses controlled by motion picture producers. ${ }^{22}$

Judge Leibell's opinion included a few other statements that do not affect the issue whether ASCAP violated the Sherman Act, but illustrate the difficulties involved in devising equitable relief that will be in the aggregate public interest. Thus, the court found that "per piece" licenses were commercially impractical and were never asked for. ${ }^{23}$ Also, if the producer paid for the performing right, this extra cost would probably be passed on to the exhibitor in his total film rental; the exhibitors would not have gotten the performing rights "free." The license fee was negotiated by two organized groups, ASCAP and the exhibitors' trade association.

Shortly after the Alden-Rochelle case was decided, Chief Judge Nordbye of the Federal District Court in Minnesota, in N. Witmark and Sons v. Jensen, ${ }^{24}$ endorsed Judge Leibell's conclusion that ASCAP was a price-fixing combination in violation of Section I of the Sherman Act, and had achieved monopolistic domination of the music integrated in sound films in violation of Section 2 of that Act. This was an action by publisher members of ASCAP for damages for copyright infringement and for injunctive relief. This court did not, however, find it necessary to determine whether there was a conspiracy between motion picture producers and ASCAP to split license rights, in order to create greater revenues for the two groups. Judge Nordbye denied equitable relief to the plaintiffs on the basis that the monopoly of the individual copyright owner had been unlawfully extended by being tied in both to the copyrighted film monopoly and to the other copyrights under the control of ASCAP. The opinion stressed the fact that ASCAP "by a refusal to license, or by the imposition of an exorbitant performance license fee, can sound the death knell of every motion picture theater in America"; was quite detailed in its analysis of the

${ }^{20}$ United States v. Paramount Pictures, Inc., 334 U. S. I3I (r948).

21 United States v. Line Materials Co., 333 U. S. 287 (1948).

${ }^{22}$ Edward H. Morris \& Co. v. Warner Bros. Pictures, S. D. N. Y. Civil Action 56-r82. This case has been settled by consent.

${ }^{23}$ Cf., in accord, Buck v. Harton, 33 F. Supp. ror4 (M. D. Tenn. 1940), findings I3, I7 and 22.

24 80 F. Supp. 843 (D. Minn. I948). 
impracticability of "per piece" licensing; and suggested that the simplest plan would be for the members of ASCAP to issue both synchronization and performance rights to motion picture producers.

\section{B. New Bottles for New Wine}

The Alden-Rochelle and Witmark $v$. Jensen opinions laid bare legal infirmities in ASCAP's organization and functioning that could not adequately be dealt with in a proceeding involving private parties with limited legal and economic interests to be adjudicated and conserved by the court. Furthermore, the opinion coincided with strong indications that a prior Consent Decree entered by the government against ASCAP in I94r was in need of revision. This earlier Decree had done little more than assuage the radio-broadcasting industry's antitrust grievances against ASCAP; it needed to be accommodated to the impact of television and other new developments within the mass entertainment field. Furthermore, it was proving a most fertile source of complaints to the Department of Justice, both from the users of ASCAP's music and from the membership of ASCAP itself.

Negotiations were accordingly commenced for a complete overhauling of the earlier document. When agreement was finally reached, in March 1950, the Amended Consent Judgment was submitted, with justificatory briefs by counsel for the treble damage plaintiffs, and by ASCAP and by the Department of Justice, to Judge Leibell for his concurrence. It was submitted for approval and signature on March 14, $195^{\circ}$ to Judge Goddard, who had signed the original Consent Decree of 194r. And counsel for the plaintiffs in the Alden-Rochelle case, after referring to the broader scope of public (as contrasted with private) antitrust proceedings, stated that "we have in this consent judgment all of the protections and redresses and ameliorations that the plaintiffs in the Alden-Rochelle suit sought, and we have certain which go beyond that." ${ }^{25}$

Let us now turn to those features of the Amended Consent Judgment of March I4, $195^{\circ}$ which concern the motion picture industry, with a view to determining to what extent they remedy the abuses so carefully delineated in Judge Leibell's opinion. And, in so doing, let it be repeated that neither the government, nor ASCAP's counsel, nor Judge Goddard made any statement, finding, or determination as to the legality or illegality of ASCAP's organization or functioning.

I. Licensing at the Source. It was an economic anomaly that, of all the manifold costs of producing a motion picture, the only one which was assessed directly against the theatre exhibitor was the cost of the performance right. This was probably a fortuitous hang-over from the time of the silent motion picture, when the theatre owner provided his own piano player as musical accompaniment. In the case of a sound motion picture, the theatre exhibitor had absolutely no control over the music that was an integral part of his rented sound film; he had to accept, as a fait accompli, an inseparable visual-auditory melange. Also the theatre owners (I7,000 of them)

\footnotetext{
${ }^{25}$ See transcript of court hearing of March 14, I950 (Civ. I8-6).
} 
were in a much weaker bargaining position with respect to ASCAP than any of the few motion picture producers.

Accordingly, the Amended Judgment contains blanket prohibitions against ASCAP

granting to, enforcing against, collecting any monies from, or negotiating with any motion picture theatre exhibitor concerning any motion picture performance rights. (Section IV (E)

instituting or threatening to institute, or maintaining or continuing any suit or proceeding against (I) any motion picture theatre exhibitor for copyright infringement relating to motion picture performance rights. ... (Section IV (F) in part.)

Having thus insulated ASCAP from any further pressures against, or other contact with, the exhibitor with respect to sound motion pictures, the Amended Consent Judgment, in Section V(C), orders and directs ASCAP

to issue, upon request, licenses for rights of public performance of compositions in the ASCAP repertory as follows: . . To any person engaged in producing motion pictures (herein referred to as a "motion picture producer"), so long as ASCAP shall not have divested itself of such rights, a single license of motion picture performance rights covering the United States, its territories and possessions, without requiring further licenses.

Under this provision, ASCAP's licensing of the motion picture performance rights under its control becomes a one-shot affair, paid for by the motion picture producer as part of his total costs of film production. As has been stated, the synchronization right is enforceable against a single industrial act-the sound-recording. Thus, producer and exhibitor are relieved by the new judgment of the contingent and unassessable liability of future infringement suits for sound film performances, sometimes taking place long years after the film was produced; and the sound film is freed of an encumbrance on its future negotiability.

During the period between the handing down of the Alden-Rochelle opinion and the entry of the Amended Consent Judgment, the right of motion picture producers and exhibitors to record and play ASCAP music, and the question of whom to compensate for the use of that music, was pretty much up in the air. Some producers made no payments; others obtained licenses for motion picture performance rights directly from members of ASCAP and paid monies to such members. Accordingly, a transitional provision in the Amended Consent Judgment stipulated, in the case of producers who had made such direct payments, that "ASCAP shall allow the motion picture producer a credit against the amount otherwise payable, equal to the amount paid under the previous license." (Section $V(C)(4)$.)

Licensing at the source (e.g., licensing of the motion picture producer rather than the exhibitor) is further implemented in the Amended Consent Judgment by a direction to ASCAP to provide in its Articles of Association that a member could not grant a synchronization or recording right to any motion picture producer unless he or ASCAP grants corresponding performance rights. (Section XII(B).) This tends to encourage concurrent negotiation for performance and synchronization 
rights and cuts down on the power of ASCAP or its members, after a license of the synchronization right has been negotiated to pursue the motion picture industry into the indefinite future for royalties on performance rights.

2. Other Limitations on Exercise of Performance and Synchronization Rights. Under Section XII(A) of the Judgment, an ASCAP member is prohibited (here also by the mechanism of an article which ASCAP is required to include in its Articles of Association) from bringing or maintaining any proceeding for acts of infringement of motion picture performance rights "( $I$ ) alleged to have occurred prior to the date of this Judgment, or (2) where corresponding synchronization rights have been granted prior to the date of this Judgment." This provision ${ }^{26}$ has three justifications. First, it serves to protect the motion picture industry from a multiplicity of individual lawsuits, based on past infringements of rights illegally asserted. Second, it is designed to dissipate the effects of past illegal restraints, to which the individual members of ASCAP had contributed. ${ }^{27}$ Third, the misuse of the synchronization right-“conspiratorially" severed from the performing right of which it is an indispensable economic corollary-is legal justification for not permitting the alleged conspirators further monetary rewards on the correlative performance right that should have been concurrently negotiated.

Incidentally, Section XII also testifies to the fear of resultant chaos and inconvenience in the licensing of performance rights if ASCAP transferred its motion picture performance rights back to its members. This prospect on the whole leads ASCAP's users "rather to bear those ills we have, than fly to others we know not of"- the risk of heavy economic burdens and untold administrative complexities and stalemates that would result from a system of individual licensing of performance rights.

ASCAP is further prohibited, in Section IV(H) of the Amended Consent Judgment, from

asserting or exercising any right or power to restrict from public performance for profit by any licensee of ASCAP any composition ... for the purpose of permitting the fixing or regulating of fees for the recording or transcribing of such composition.

This injunction restrains ASCAP from abusing its leverage in the performance rights field, which is its only legitimate domain, to secure advantages in connection with synchronization or other recording rights. The only exceptions to this principle are that ASCAP may, when directed by a member, restrict performances of a composition in order to protect it against indiscriminate performances, or to protect the value of the public performance for profit or dramatic performing rights therein;

${ }^{20}$ Which, from a practical standpoint, qualifies an ASCAP member's right of withdrawal from ASCAP (see p. $3 I_{4}$ infra) and his right individually to license performance rights (see p. 3 I9 infra).

${ }^{27}$ Patents which have been illegally abused have been declared legally unenforceable (see Morton Salt Co. v. G. S. Suppiger Co., 3 I4 U. S. 488 (I942); B. B. Chemical Co. v. Ellis, 3I, U. S. 495 (I942); final judgment in United States v. General Electric Co., D. N. J., Comarerce Clenring House Trade Regulation REPORTS 967,576 (1953)), or have been subjected to compulsory licensing (see HartfordEmpirc Co. v. United States, 323 U. S. 386 (I945); United States v. National Lead Co., 332 U. S. 319 (1947)). 
and that performances may be restricted so far as reasonably necessary in connection with claims or litigation. The frrst of these exceptions, rather than indicating ASCAP's power, protects the individual members of ASCAP by reserving their rights.

3. The Motion Picture Producers' Conflicting Interests. Motion picture producers are users of copyrighted music; music publishing houses are producers of such music. A music publishing house that is a subsidiary of a motion picture producer (as was true of some ASCAP members) therefore has a conflict of interest-the consumer's desire to buy cheap versus the producer's striving to sell dear. To eliminate this conflict, Section $\mathrm{V}(\mathrm{C})(5)$ of the Amended Judgment provides that:

No writer or publisher member of the Board of Directors of ASCAP shall participate in or vote on any question relating to the negotiation, execution, performance or enforcement of any such license where such member at the time, directly or indirectly, has any pecuniary interest in any motion picture producer, in any subsidiary or affiliate of any motion picture producer, or in any contractual relationship with any such producer.

The further contention has been raised, in the private treble damage suit already referred to, ${ }^{28}$ that the relationship between the motion picture producer and his affiliated music publishing house is a restraint of trade; the relationship is charged to foreclose competitors of the publisher in question (the publishers, composers, and authors represented in other catalogues) from access to the particular motion picture producer as a market for their compositions. Whatever the merits of this contention, which derives legal impact from recent cases outlawing "tie-in" arrangements, ${ }^{20}$ full requirement contracts, ${ }^{30}$ and exclusive dealerships, ${ }^{31}$ the proper vehicle for formally lodging and disposing of such a contention is a legal proceeding against the specific movie producers and publishing houses in question. A modification of a consent decree in which ASCAP is the sole defendant can take account of this conflict of interest only to the extent that it criss-crosses the total pattern of combination and conspiracy.

4. Facility for Economic Review and Legal Revision. There are several injunctive provisions in the Amended Judgment which stem from doubts whether the licensing of motion picture performance rights takes place in the same type of industrial complex as the licensing, let us say, of radio performing rights. The production of a motion picture is indubitably a hectic affair, but it does seem possible to select in advance the music that is to be incorporated in a film, or in a studio's annual production schedule; the motion picture producer would not appear to have the same necessity as the broadcaster and bandleader for immediate availability to any part of the ASCAP repertory. Accordingly, the all-inclusive single license of performing

${ }^{28}$ See note 22, supra.

${ }^{20}$ International Salt Co. v. United States, 332 U. S. 392 (1948).

${ }^{30}$ See Federal Trade Commission v. Motion Picture Advertising Service Co., Inc., 344 U. S. 392 (1953) (Section 5 of Federal Trade Commission Act); United States v. American Can Co., 87 F. Supp. I 8 (N. D. Calif. x949).

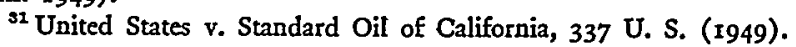


rights provided for by the Amended Consent Judgment has been further "limited to pictures produced or in production not later than one year after the effective date of the license." Such licenses are, upon the producer's written request, to "be issued on a 'per film' basis for the compositions in such film which are in the ASCAP repertory," and they are to "be negotiated with and issued to individual motion picture producers, and not on an industry-wide basis." (See Section V(C)(r), (2), (3).)

As a further expression of doubt as to the permanence of the judgment arrangements for the licensing of motion picture performance rights, the government may, "any time within two (2) years from said date [i.e., of entry of judgment] apply to this Court for the vacation or modification of Section V(C) hereof," i.e., the provison governing the licensing of motion picture performance rights. This short period contrasts with applications for the vacation or modification of the judgment in other respects (including the dissolution of ASCAP), which may be made at any time after five years from the time of entry of the Judgment. Both provisions are in addition to the standard provision which has been incorporated for a long time in all consent judgments, to the effect that:

Jurisdiction of this cause is retained for the purpose of enabling any of the parties to this Amended Final Judgment to make application to the Court for such further orders and directions as may be necessary or appropriate in relation to the construction of or carrying out of this Judgment, for the modification thereof, for the enforcement of compliance therewith and for the punishment of violations thereof. (Section XVII.)

\section{II}

\section{The Radio and Telecasting Industry Versus ASCAP}

The motion picture provisions that have just been described were part of a general revamping of an older antitrust Consent Decree of March 4, I941, which had put a temporary legal quietus to a long campaign of open hostility between ASCAP and the industry that was the strongest and best organized user of ASCAP's music-radio broadcasting. The radio provisions of this earlier decree were to a considerable extent a relatively stable component of ASCAP's $195^{\circ}$ antitrust situation. There attached to them that presumption of continuing adequacy and operation in the public interest inherent in any antitrust court judgment; any modification of them would require a conclusive showing that the provisions of the judgment had become needlessly and unduly harsh on the defendant, ${ }^{32}$ or were no longer calculated to serve the public interest, or were unattuned to changed conditions. ${ }^{33}$

The I94I decree could not, in I950, be said to be oppressive to ASCAP. However, both the technology of mass communication and the economic conditions of the mass entertainment industries had changed radically in that interval, and the I94I decree was not responsive to these changed circumstances. Also, a steady stream

\footnotetext{
${ }^{33}$ International Salt Co. v. United States, supra note 29; McComb v. Jacksonville Paper Co., 336 U. S. I87 (1949).

${ }^{33}$ United States v. Swift \& Co., 286 U. S. I06 (1932); United States v. International Harvester Co., 274 U. S. 693 (1927).
} 
of complaints to the Department of Justice, many of them raising antitrust questions, had indicated a well-grounded dissatisfaction with the operation of the decree. Furthermore, some of the general principles underlying the rearrangement of the prevailing pattern for the licensing of motion picture performance rights were applicable to other media of mass communication and entertainment. In this light, let us now examine the basic changes made by the I950 Judgment with respect to the licensing of radio and related performance rights.

\section{A. The I94I Tug of War and Its Resolution}

The bargaining relationship between ASCAP and the radio industry is one of those situations of "countervailing power" so lucidly described by Professor Galbraith in his recent book. ${ }^{34}$ Radio broadcasting is an industry not without its own antitrust aspects, some of them the subject of past legal inquiry, others a matter of current economic disquiet and surmise. The industry is dominated by four massive networks, which are central programming agencies for their respective affiliated stations; these networks are subject to Federal Communications Commission regulation, which has attempted, with what some say has been indifferent success, to create some antitrust safeguards in their operation. ${ }^{35}$ There is a great amount of industry interpenetration-owners of radio stations usually control both AM and FM modes of radio-casting, and frequently have ownership interests in newspapers, motion pictures, and other media of mass communication. ${ }^{36}$ The networks and independent radio stations are cohesively organized for purposes of negotiating, with ASCAP, standard contract forms for the licensing of ASCAP's music. The radio broadcasting industry also owns a performance rights licensing organization, Broadcast Music, Inc. (BMI), with a very much smaller and less valuable repertory than ASCAP but with a direct ownership connection with the radio industry. ${ }^{37}$

The 194I Consent Decree against ASCAP had been preceded by a whole year in which radio broadcasters had abstained from any use of ASCAP music, and had subsisted entirely on music controlled by BMI or in the public domain. Its entry was accompanied by the simultaneous entry of a consent judgment against BMI, ${ }^{38}$ which, despite its considerably smaller economic impact, was subject to alleged legal infirmities somewhat akin to those of ASCAP.

34 John K. Gazbratth, American Capitalism-The Concept of Countervallino Power (1952).

${ }^{35}$ E.g., Federal Communications Commission, Report on Chain Broadcasting, Docket 5060 (194I); Columbia Broadcasting System v. United States, 316 U. S. 407 (1942); National Broadcasting Co. v. United States, 3 Ig U. S. I90 (1943).

${ }^{30}$ See Morris L. ERnST, The FIrst Freedons c. V (1946); Federal Communications Commission, Summary of Record on Press Radio Hearings, Docket 605I (1943); Weaver and Cooley, Competition in the Broadcasting of Ideas and Entertainment-Shall Radio Take Over Television?, xor U. of PA. L. Rev. 721 (1953); Federal Communications Commission, Hearings on Paramount-ABC mergcr, F.C.C. Docket No. roo3i et al. (1952).

${ }^{37}$ As this article goes to press, a class antitrust proceeding has been filed by a group of song writers against BMI, the radio and television networks, and some record and music publishing companies owned by one of the networks. The complaint asks for the dissolution of the National Association of Radio and Television Broadcasters, the divorce of BMI from radio ownership, and damages in the amount of I50 million dollars. New York Times, Nov. II, I953, p. 4I, cols. 4-5.

${ }^{38}$ United States Broadeast Music, Inc., D. Wis. (I94I). 
The r94I ASCAP Decree was, as far as ASCAP's relations with music users were concerned, largely confined to stating, in legal injunctive language, some of the ground rules which were to govern the prices and other terms and conditions under which radio stations were to be licensed to use ASCAP music. The standard "blanket" and "per program" licenses, and the schedule of payments originally negotiated between ASCAP and the radio industry on the basis of their I94I concordat, were still accepted by both sides in I950. Hence, with the exceptions noted in this section, the radio broadcasting provisions of the old decree were carried over substantially unchanged into the new. For purposes of completeness, however, these provisions will be set forth in an appendix at the end of this article.

I. Automatic Grant of License Rights. The one year's impasse, during which ASCAP music was withdrawn from the airwaves and the public deprived of its radio reception, points to one of the disconcerting and unanswered dilemmas that flow from the doctrine of "countervailing power." This doctrine assumes that many industrial outfits are strong enough to withhold their goods, services or payments until the other (countervailing) side meets its terms, and that this check on the arbitrary exercise of power protects the public interest. Thus, in I94 $\mathrm{I}$, the radio industry was strong enough to do without ASCAP music and ASCAP was financially able to sit out a campaign of attrition and no radio revenues. But, query as to the public interest? Did not the public suffer at least an aesthetic detriment in being deprived of ASCAP music?

To obviate a recurrence of this stalemate, Section V(A) of the Amended Consent Judgment of 1950 orders and directs ASCAP to issue licenses upon request to radio broadcasting networks. This is a strengthening of a I94I Consent Decree provision enjoining ASCAP from refusing to offer licenses at a fee. During the neardecade between the original decree and the Amended Consent Judgment, the law had definitely established the legal propriety of the courts, in situations involving antitrust abuse, ordering the compulsory sale of products ${ }^{39}$ or the compulsory licensing of patents. ${ }^{40}$ From this, it was but a slight step to requiring ASCAP to license performance rights.

2. Tudicial Fixing of Reasonable License Fees. We have thus far seen how ASCAP has been deprived of the power to withhold its repertory from use by either the radio broadcaster or the motion picture producer; in fact, the r950 decree grants all users an automatic right to use the ASCAP inventory. What had made ASCAP particularly vulnerable, both in the Alden-Rochelle and Witmark v. Jensen cases and in prior litigation involving state statutes, ${ }^{41}$ however, was its power to fix prices for the use of its repertory. Furthermore, not all the prospective users of ASCAP's repertory have the financial capacity of radio and motion pictures to absorb fees

\footnotetext{
${ }^{30}$ International Salt Co. v. United States, supra, note 29; United States v. Besser Mfg. Co., 343 U. S. 444 (1952).

"Hartford Empire Co. v. United States, supra, note 27; United States v. National Lead Co., supra, note 27 .

${ }^{11}$ See, e.g., Watson v. Buck, supra, note I2; Buck v. Gallagher, supra, note 9.
} 
retroactively assessed after protracted periods of negotiation. Smaller users required, and larger users should have, the right to enlist the government's aid in the determination of a reasonable license fee.

Accordingly, there was adapted, from procedures which had evolved in connection with the compulsory licensing of antitrust defendants' patents, ${ }^{42}$ a procedure whereby an ASCAP licensee, in the event of disagreement as to a reasonable fee for his license, could enlist the aid of the Federal District Court in the determination of such a fee. This provision is worth setting out in full:

IX(A) Defendant ASCAP shall, upon receipt of a written application for a license for the right of public performance of any, some or all of the compositions in the ASCAP repertory, advise the applicant in writing of the fee which it deems reasonable for the license requested. If the parties are unable to agree upon a reasonable fee within sixty (60) days from the date when such application is received by ASCAP, the applicant therefor may forthwith apply to this Court for the determination of a reasonable fee and ASCAP shall, upon receipt of notice of the filing of such application, promptly give notice thereof to the Attorney General. In any such proceeding the burden of proof shall be on ASCAP to establish the reasonableness of the fee requested by it. Pending the completion of any such negotiations or proceedings, the applicant shall have the right to use any, some or all of the compositions in the ASCAP repertory to which its application pertains, without payment of any fee or other compensation, but subject to the provisions of Subsection (B) hereof, and to the final order or judgment entered by this Court in such proceeding;

(B) When an applicant has the right to perform any composition in the ASCAP repertory pending the completion of any negotiations or proceedings provided for in Subsection (A) hereof, either the applicant or ASCAP may apply to this Court to fix an interim fee pending final determination of what constitutes a reasonable fee. If the Court fixes such interim fee, ASCAP shall then issue and the applicant shall accept a license providing for the payment of a fee at such interim rate from the date of the filing of such application for interim fee. If the applicant fails to accept such license or fails to pay the interim fee in accordance therewith, such failure shall be ground for the dismissal of his application. Where an interim license has been issued pursuant to this Sub-section (B), the reasonable fee finally determined by this Court shall be retroactive to the date the applicant acquired the right to use any, some or all of the compositions in the ASCAP repertory pursuant to the provisions of this Section IX;

(C) When a reasonable fee has been finally determined by this Court, defendant ASCAP shall be required to offer a license at a comparable fee to all other applicants similarly situated who shall thereafter request a license of ASCAP, but any license agreement which has been executed without any Court intervention between ASCAP and another user similarly situated prior to such determination by the Court shall not be deemed to be in any way affected or altered by such determination for the term of such license agreement;

(D) Nothing in this Section IX shall prevent any applicant or licensec from attacking in the aforesaid proceedings or in any other controversy the validity of the copyright of any of the compositions in the ASCAP repertory nor shall this Judgment be construed as importing any validity or value to any of said copyrights.

\section{Application of Similar Principles to Television, Wired Music Services, Trans-}

42 And substantially upheld in United States v. U. S. Gypsum Co., 340 U. S. 76 (1950). 
scriptions, etc. Under Section VI of the Amended Consent Judgment, ASCAP must "grant to any user making written application therefor a non-exclusive license to perform all of the compositions in the ASCAP repertory." This merely universalizes the principle of compulsory licensing, already discussed in connection with radio and motion pictures. Also, all users of ASCAP music may, if they fail to reach agreement with ASCAP, have recourse to the court procedure for the determination of a reasonable fee that has just been set forth.

The principle of licensing at the source had been established for radio performance rights in I94I, and was made mandatory for motion picture performance rights by the I950 Judgment. Section $\mathrm{V}(\mathrm{A})$ of that judgment also makes the principle applicable to television and wired music services (such as "Muzak"). The technology and economics of these two entertainment industries (one of them just getting under way in r94r, and the other then much smaller than at present) were similar enough to that of radio to justify similar time- and trouble-saving mechanics of licensing.

Manufacturers, producers, and distributors frequently make electrical transcriptions or other specially prepared recordations for radio broadcasting or television broadcasting purposes. Section V(B) of the Amended Consent Judgment authorizes such manufacturers, producers, and distributors to obtain a single license from ASCAP which will

authorize the broadcasting, by radio or by television, as the case may be, of the recorded composition by means of such transcription or recordation by all radio stations or television stations in the United States enumerated by the licensee, without requiring separate licenses for such enumerated stations for such performance.

This also means licensing ASCAP music at the source.

4. General Restrictions on ASCAP Powers. There are some general injunctions in the $195^{\circ}$ Judgment which further limit ASCAP's powers with respect to any user of its music. First, ASCAP is limited to the public performance rights field. Section IV (A) enjoins it from

holding, acquiring, licensing, enforcing, or negotiating concerning any rights in copyrighted musical compositions other than rights of public performance on a non-exclusive basis.

Second, ASCAP is prohibited from discriminating against any licensees which are similarly situated. Section IV(C) forbids ASCAP from

entering into, recognizing, enforcing or claiming any rights under any license for rights of public performance which discriminates in license fees or other terms and conditions between licensees similarly situated.

Third, ASCAP is in the future prohibited from granting any performance rights licenses of more than five years' duration. (See Section IV(D).) The only exception is motion picture performance rights, where, as has been shown, the physical integration of the performed musical composition into the film dictates a 
different economic result. ${ }^{43}$ This provision, in addition to promoting more frequent occasions for economic initiative by licensees, facilitates the government's job should circumstances compel it to reopen the Judgment.

Fourth, an ASCAP negotiator with the users of its music should not be involved in any conflict of interest that might raise an inference either of collusive action with licensees or dilution of the negotiator's loyalty to ASCAP. Accordingly, Section $\mathrm{X}$ of the Judgment generalizes the provision which has already been discussed with respect to motion picture performance rights, by providing that:

No officer or director of ASCAP, or any person acting on its behalf, shall participate in or vote on any question relating to any transaction or negotiation involving ASCAP and a licensee, or prospective licensee, where such officer, director, or other person has any pecuniary interest in such licensee or prospective licensee, or in any subsidiary or affiliate thereof, or in any contractual relationship with any such licensee or prospective licensee.

Fifth, Section VIII of the Amended Consent Judgment in effect requires ASCAP to use its best efforts to give licensees a genuine choice from among various types of licenses offered by it. Under it, ASCAP is

ordered and directed to use its best efforts to avoid any discrimination among the respective fees fixed for the various types of licenses which would deprive the licensees or prospective licensees of a genuine choice from among such various types of licenses.

The specific impact of this rather general language can perhaps be better visualized by studying the problem of the relation of "per program" to "blanket" licenses, to which we now turn.

5. "Per Program" Licenses. As a matter of linguistic purity, all ASCAP radio licenses are blanket licenses, in that they entitle the station to use the entire ASCAP repertory. Most radio stations play ASCAP music on substantially all their programs, but others make a much more limited use of ASCAP music. Accordingly, the 194I Decree had contained an obligation on ASCAP to offer a "per program" license to stations desiring to use ASCAP music for particular programs, in a manner designed "to afford radio broadcasters alternative basis of license compensation."

The content of this obligation (only part of which has just been reproduced) had, because of a somewhat tortuous and indirect formulation, been unclear. There was substituted more forthright language to the effect that there be no discrimination among various types of license fees that would deprive licensees of a genuine choice from among various types of licenses.

Section VII(B) (3) further stipulated that the fee for a "per program" license take into consideration the economic requirements and situation of those stations having relatively few commercial announcements and a relatively greater percentage of sustaining programs, with the objective that such stations shall have a genuine economic choice between per program and blanket licenses.

This provision is intended to protect the so-called "good music" stations, which have small commercial revenues.

\footnotetext{
${ }^{43}$ See p. 302 supra.
} 
The problem at which these two judgment provisions are aimed continues, however, to plague the entertainment industry. Recently, some fifty television stations, unable to reach agreement with ASCAP on the terms of a "per program" television license, brought a proceeding under Section IX of the Amended Consent Judgment calling upon the District Court to fix a reasonable fee. ${ }^{44}$ ASCAP had based its demands largely on the fact that the combined visual-auditory nature of a television performance gave the television rights to its repertory a greater value than radio rights would have. The telecasters, on the other hand, had asserted in behalf of a lower fee the very high developmental costs encountered in the television field, running to many times those involved in radio broadcasting. There are other contentions involved in this proceeding, and it is safe to predict, from the novelty of the proceeding and the experience in prior court efforts to determine reasonable patent royalties, ${ }^{45}$ that the District Court will not soon be rid of this controversy, unless it is amicably settled.

\section{III}

\section{ASCAP VERSUS ASCAP}

ASCAP is an emotionally precarious alliance between the creators and the promoters of popular and classical music, cemented together by the hard realities of business self-interest. There has been no serious dispute about one salient feature of ASCAP's organization-the 50-50 basis on which its 599 publishers and 2,672 "participating" writers (composers and authors) divide both its control and its net revenues. Even here, however, there are occasional rifts in the domestic lute. Thus, there is the ambivalent status of the music publishers affliated with motion picture producers. Also, there are occasional problems when composers or authors turn out to have interests in publishing firms.

ASCAP's basic internal problem, however, is not the relationship of the publisher group to the writer group, but the relationship of ASCAP as an organization to its individual publisher and writer members. ASCAP is not a labor union, for its members are in no employer-employee relation to the users of ASCAP music. ${ }^{46}$ In an empirical sense, however, it does play the role of a collective bargaining representative for its members vis à vis those users.

One can therefore apply to ASCAP what Chief Justice Stone has said of a labor union, that it: $:^{47}$

... is clothed with power not unlike that of a legislature which is subject to consti-

"In the Matter of Application of Voice of Alabama for the Determination of Reasonable License Fees, filed July 18, 195 I (Civil Action No. 13-95).

${ }^{6} \mathrm{As}$, for example, in the controversy as to reasonable royalties which followed the Supreme Court decision in the Hartford Empire case, supra, note 27; 65 F. Supp. 27x (N. D. Ohio 1946); Comment, Compulsory Patent Licensing by Antitrust Decree, 56 YALE L. J. 77, 90 (1946); and the District Court's decision in United States v. Vehicular Parking, Ltd., 54 F. Supp. 828 (D. Del. 1944), modified, 56 F. Supp. 297 (D. Del. 1944), judgment modified, 6r F. Supp. 656 (D. Del. 1945).

${ }^{\circ} \mathrm{Sec}$ Ring v. Spina, 148 F. 2d 647,652 (2d Cir. 1945).

${ }^{47}$ Steele v. Louisville and Nashville R. R., 323 U. S. 192, I98 (1944); cf. Railway Mail Ass'n v. Corsi, 326 U. S. 88 (I945). 
tutional limitations on its power to deny, restrict, destroy, or discriminate against the rights of those for whom it legislates and which is also under an affirmative constitutional duty equally to protect those rights.

If one has regard to the tremendous economic powers which ASCAP wields over its members-particularly those who depend on it for their livelihood-there devolves upon ASCAP an obligation to observe a minimum standard of corporate democracy and fairness, which will insure that certain minimum rights of its members are not abnegated. These guarantees of "microcosmic due process," as it were, cannot however be allowed to become a set of specific corporate blueprints and admonitions, because this would be counter to the principles of equity jurisprudence and beyond the proper function or innate ability of a court.

The detailed bulk of ASCAP's internal relationships with its members must therefore be left to the sense of fair play and to the business acumen of the organization and its members. As a minimum, however, ASCAP members should be free to associate in, or to disassociate themselves from, ASCAP. Judge Wyzanski, in an illuminating article, has advanced "the open window and the open door" as the symbols of the future evolution of the principle of freedom of association: ${ }^{48}$

Through the window not only the government but indeed any merely curious outsider may see the character of the organization. Through that door may enter any one who subscribes in good faith to the announced purposes of the organization and who seeks to maintain its hospitality. And through that door those who so desire may freely leave.

The way in which the three objectives enumerated by Judge Wyzanski are integrated into ASCAP's reorganized framework will be set forth in separate sections, dealing respectively with:

I. Right of entry into ASCAP.

2. Right of exit from ASCAP.

3. The open window.

The Amended Consent Judgment of r950 goes somewhat beyond Judge Wyzanski's minimum requirements, and contains other provisions protective of members' rights while they remain in ASCAP. These will be discussed in sections dealing respectively with:

4. Voting procedures and control.

5. Standards of revenue distribution.

6. Opportunity of impartial review.

7. Right of individual licensing.

r. Right of Entry Into ASCAP. The basic economic freedom guaranteed by the Sherman Act is the freedom of an individual to engage in a trade or profession. ${ }^{40}$ Complaints have been made by many composers and authors that ASCAP's refusal

\footnotetext{
${ }^{4}$ The Open Window and the Open Door, 35 CALIF. L. Rev. 336, 349-350 (I947).

10 Addyston Pipe and Steel Co. v. United States, I75 U. S. 2 II (1899); Anderson v. Ship-Owners Ass'n of the Pacific Coast, 272 U. S. 359 (1926).
} 
to accept them for membership was an economic deterrent to the commercial acceptance of their compositions, and hence impaired their existence as song writers. It is impracticable to pass judgment on the merits of this complaint in individual cases; many individuals may well have exaggerated notions as to the commercial viability of their musical talents. The only safe policy for ASCAP to pursue, if individuals are to be protected, is that of relatively unrestricted admission to membership. ${ }^{50}$ Accordingly, ASCAP is required by Section XV of the Amended Consent Judgment to admit to membership:

(A) Any composer or author of a copyrighted musical composition who shall have had at least one work of his composition or writing regularly published.

(B) Any person, firm, corporation or partnership actively engaged in the music publishing business, whose musical publications have been used or distributed on a commercial scale for at least one year, and who assumes the financial risk involved in the normal publication of musical works.

ASCAP is permitted by the Judgment to have both participating and nonparticipating members; this has current significance only for the writers. However, the Society's Articles of Association (which represent part of ASCAP's pattern of compliance with the Amended Judgment but have neither Justice Department nor Court approval) contemplate that non-participating writer members (whose works obtain only limited performances and who therefore receive inconsequential royalties from ASCAP) be transferred to the appropriate participating class at yearly intervals, upon a showing that they regularly practice the profession of writing music or the text or lyrics of musical works. Furthermore, non-participating members are entitled, under the Articles, to receive royalty distributions made solely on the basis of current performances; and cannot be discontinued except upon a showing that their performances during no one of five preceding years have resulted in a royalty distribution to the member equal to current annual dues (which are quite nominal).

In the case of publishers, ASCAP has, under the Amended Consent Judgment and its new Articles of Association, the power to keep from its membership so-called "song-shark" publishers, i.e., publishers who obtain money from composers and authors on the promise that they will exploit their works commercially but do not do so and are not equipped for such exploitation.

ASCAP's membership is, of course, to a large extent, a function of economic conditions and the financial security that prospective members see in it. Nevertheless, it seems significant that, while the writer membership of ASCAP, as of January I, I950, was 2,040 , the present writer count is 2,672 participating class members and 27 non-participating class members. During the same period, the publisher membership increased from 365 to 599, all of which are participating class members.

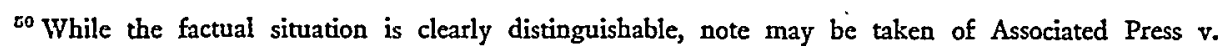
United States, 326 U. S. I (I945), where newspaper publishers "by concerted arrangements, pooled their power to acquire, to purchase, and to dispose of news reports" (page 16). The Supreme Court held that the articles of association of the Associated Press contained restrictive clauses on admission to membership which, taken in context with other factors, violated the Sherman Act. 
2. Right of Exit From $A S C A P$. Grave objection had been registered to the system that had prevailed under the I94x Consent Decree, because a withdrawing member could not take out of ASCAP performing rights which he had assigned to ASCAP. Moreover, his contract with ASCAP called for the assignment of all future performing rights acquired by him for a period of 25 years.

Section IV(G) of the Amended Consent Judgment puts an end to this situation by prohibiting ASCAP from

restricting the right of any member to withdraw from membership in ASCAP at the end of any fiscal year upon ( $I$ ) giving three months' advance written notice to ASCAP, and (2) agreeing that his resignation shall be subject to any rights or obligations existing between ASCAP and its licensees under then existing licenses and to the rights of the withdrawing member accruing under such licenses.

Thus, the only restriction on the right of a member to withdraw is that he recognize such contracts as ASCAP has already entered into on his behalf. He continues to receive revenues accruing in respect of performances licensed under these ASCAPnegotiated contracts. Since ASCAP is prohibited in general from granting any license in excess of five years' duration (see Section IV(D)), this means that, within a short time, any member who withdraws from ASCAP would be legally capable of licensing his entire catalogue of musical compositions.

3. The Open Window. A recurring criticism of ASCAP during the years had been its failure to make public disclosure of the reasons underlying the actions of its Board of Directors-particularly those actions that concerned the all-important issue of membership classification for revenue distribution purposes. This had given rise to a continuing barrage of complaints and innuendoes concerning "insider control," favoritism, etc. As Lord Acton has put it: "Everything secret degenerates; nothing is safe that does not show how it can bear discussion and publicity." XIII(B) of the Amended Consent Judgment accordingly provides

that the general basis of member classification for voting and revenue distribution purposes shall be set forth in writing and shall be made available to any member upon request.

An opaque façade which ASCAP was alleged to have wrongfully presented to the users of its music was the bringing of infringement suits on compositions which users asserted were not known to them to be within the ASCAP repertory. This, of course, affected primarily the rights of the users of ASCAP's music. In order to rectify this situation and provide an "open window" on this phase of ASCAP's operations, Section XIV of the $195^{\circ}$ Judgment requires that:

ASCAP shall upon written request from any prospective user inform such user whether any compositions specified in such request are in the ASCAP repertory, and make available for public inspection such information as to the ASCAP repertory as it has.

The same section further directs ASCAP

\footnotetext{
${ }^{51}$ Sce Nichols, Lotd Acton, I UNIVERsity OBSERver 14 (U. of Chic., 1947).
} 
to prepare within two years, and to maintain and keep current and make available for inspection during regular office hours, a list of all musical compositions in the ASCAP repertory, which list will show the title, date of copyright and the author, composer and current publisher of each composition.

ASCAP has, as a matter of fact, gone further and has distributed to its radio and television licensees a list of all its compositions which have been performed on radio or television in the past 20 years-some roo,000 in number.

These provisions are not only significant for the information they give users as to the contents of ASCAP's repertory; Section IV $(F)(2)$ of the Judgment effectively debars ASCAP, once the list is prepared, from bringing suit on any musical composition not on the list. In other words, the list prepared and made accessible by ASCAP is presumed to be its entire repertory.

4. Voting Procedures and Control. It is an unchallenged assumption of corporate democracy that persons who make a greater contribution to a business enterprise may be given a greater voice in the administration of the enterprise's affairs and a larger share in its profits. The Amended Consent Judgment recognizes this when, in connection with the voting procedure, it provides that:

Due weight may be given to the classification of the member within ASCAP in determining the number of votes each member may cast for the election of directors. (Section $\operatorname{XIII}(\mathrm{A})$.)

If the number of votes cast were the sole test of ASCAP control, it would be possible for the fifteen or twenty top writers in ASCAP to vote themselves into all the writer directorates. However, two provisions were included in the judgment to "insure a democratic administration" of ASCAP's affairs.

First, it was provided that:

The Board of Directors shall, as far as practicable, give representation to writer members and publisher members with different participations in ASCAP's revenue distribution. (Section XIII (A).)

The Articles of Association implement this provision by classifying the writer members into six groups, based upon their respective participation in ASCAP's domestic royalties during the previous calendar year. 'The writers' nominating committee is to consist of six writers, selected from each of the six groups; and the ballots for directors are to show, for each vacancy, the class or division of membership from which the nominee must be chosen. (Article IV, Section 4(b) and (f).) When these provisions are taken in conjunction with the ASCAP practice of setting aside one-fourth of the directorships for the writers and publishers of "standard music," it is no longer possible for the top-writers in ASCAP to elect only themselves to the directorate, and a more democratic representation is in fact obtained.

A recurrent criticism of the voting procedure followed by ASCAP prior to $195^{\circ}$ was that it resulted in a self-perpetuating Board of Directors. Once again, the rule in ordinary commercial enterprises is that directorates able to point to satisfactory 
business performance tend to get re-elected. ASCAP, however, had deviated from customary corporate procedures, in that its directors were elected for a three-year term and only a third of them replaced at each annual election. The opportunities for the automatic self-perpetuation of the Board in such a situation are obvious. Accordingly, the Amended Consent Judgment requires annual or biennial elections of the entire Board.

Under the Articles of Association, the writer and the publisher Committees on Nominations are respectively required, where a directorship is currently expiring, to nominate from the general membership one candidate for each publisher-directorship and two candidates for each writer-directorship; these are distinct from the incumbent directors, who are to be automatically regarded as candidates for re-election unless the Committee is otherwise instructed in writing. Where an incumbent publisher member does not stand for re-election, two candidates instead of one are to be nominated from the general membership. Furthermore, ballots are to provide a suitable blank space for names to be written in by members. (Article IV, Section 4(d) and (f).) Thus, the membership is assured of ample opportunity to consider for directorships people other than the incumbent Board members.

5. Standards of Revenue Distribution. Probably the most thorny and publicized dispute that has convulsed ASCAP's inner ranks has been the distribution of revenues among its members. While ASCAP itself engages in no promotional activities, a large number of its members are constantly on the qui vive-through all kinds of "song-plugging" and other devices-to enhance the use of music in their respective publisher or writer catalogues. ASCAP's problem is to distribute its total net revenues to its publisher and writer members on a basis that they will accept as fair and equitable.

Probably because a $50-50$ income split between the song writer and publisher had become the traditional basis of collaboration with respect to sheet music, a similar split of ASCAP's net revenues between its publisher and writer members has not undergone serious challenge. However, when it came to the allocation of individual shares, ASCAP's members, particularly the writers, have been contentious and strident indeed. Let us first canvass some of the problems that lie at the root of this clamor, and then describe the general program to resolve them envisaged by the Amended Consent Judgment.

It is impossible to set any price on the performance of an individual musical composition that will command general acceptance as a fair commercial price. When art enters the market place, market values become as debatable as aesthetic values. Thus, ASCAP numbers among its writer-members the so-called "standard" writers, who compose symphonies, sonatas, and other serious music. It is clear that an oratorio or tone-poem is not played as often as "Beat Me, Daddy, Eight to the Bar" or "The Woodpecker Song," and is played to different audiences. It would be harsh to base the revenues of the "standard" writers on the same criteria of commercial performance and acceptability that are applied to the writers of popular music. 
Furthermore, even among the "popular" writers there are some writers who verge on the semi-classical (Rudolf Friml is said to belong in this intermediate category), and are thereby said to confer a certain prestige on the organization. This is also true of individual songs. Other compositions are said to possess added value because they have a certain time-utility; "When Irish Eyes Are Smiling" may not get played very much throughout the rest of the year but is certainly in great vogue on St. Patrick's Day, and "The Anniversary Song" has an indispensability in connection with anniversaries that does not attach to other more routine occasions.

Such subjective appraisals, either of the inherent aesthetic value of the composition or of the commercial value of the audience's need for the piece, give rise to two main practical difficulties. First, aesthetic values and psychological analyses are the most variegated and non-standardized facets of human experience. Second, this kind of necessarily personal evaluation of a writer's worth, because it could not be given an objective and explicit articulation, resulted in a stream of protests that privileged insiders and unproductive writers were being unjustly permitted to skim off the cream of ASCAP revenues. Thus, one basic issue was: Can or should any standards be formulated which would permit the distribution of ASCAP revenues to take into account the relative "worth" of individual musical compositions, or individual writers?

The second main bone of contention among the ASCAP writers was the role of seniority in the making of income distributions. The entertainment industry of which ASCAP is a part is known for its generous attitude towards older artists who have fallen on evil days. Also, the earning power of ASCAP writers is frequently a matter of feast or famine. The writers desire to regularize their earnings and cushion themselves against income declines. A classic illustration is Oscar Hammerstein who, for eleven years after the phenomenal success of his "Show Boat," did not have another Broadway hit until "Oklahoma!" Moreover, the economic existence of ASCAP is dependent on its retaining the membership of approximately 50 of the top-ranking writers of the United States who, in return for assurances of long-time security given them by ASCAP, are content to set a maximum on their annual earnings that is well below what they might be entitled to on a pure performance basis.

While there were justifications for protecting seniority, there had been a constant and justified criticism that some of the older members of ASCAP, despite long years of musical non-productivity, were being compensated on a much higher basis than younger, productive writers. Since ASCAP's task was to distribute a fixed kitty, such generous over-helpings to what the trade press called the "Paddock Crowd" necessarily meant slow and discouraging recognition of younger and aspiring writers. The so-called "Young Turks" kept up a constant fire of protest against the slow rate at which deserving younger members were promoted to higher income levels within the ASCAP hierarchy, and said that if this tendency went unchecked the result would be to retard the development of popular music in this country. 
Three efforts had been made in the history of ASCAP since $x 93^{8}$ to revise the system of distribution of ASCAP revenues, but none commanded enough support to be adopted by the membership. Thus was posed the second practical question in connection with income distribution: To what extent should ASCAP allow considerations of seniority and of income stability to control the distribution of income among its members? At what rate should ASCAP compensate its younger meritorious members, and those devoted to the production of "standard" music?

The Amended Consent Judgment of $195^{\circ}$ gave no definitive answers to these questions, but formulated three broad standards, which it was hoped would enable ASCAP to arrive at a fairer and more equitable distribution of revenues. The judgment provided for, first, free, full and open publicity to its membership as to the basis to be followed in distributing revenues; ${ }^{52}$ second, primary reliance on an objective (in fact, a mathematical) basis for the apportionment of revenues; and, third, impartial review by an outside impartial arbiter of any determination as to member classification made by an organ of ASCAP.

Objectivity in the apportionment of revenues is achieved by a judgment directive to give "primary consideration to the performance of the compositions of the members as indicated by objective surveys of performances ..." (Section XI). Commercial acceptance is, after all, the least assailable criterion of economic earning power.

While ASCAP adheres primarily to an objective performance basis, it has adopted internal arrangements, made a matter of public record but not submitted for approval to either the Court or the Department of Justice, which take into consideration social and aesthetic factors other than the number of current performances. The total quarterly ASCAP revenues available for distribution are divided, accounting-wise, into three funds:
A. A Current Performance Fund of 20 per cent;
B. A Sustained Performance Fund of 60 per cent;
C. An Accumulated Earnings Fund of 20 per cent.

The 20 per cent Current Performance Fund is distributed entirely on the basis of the relative number of current performances of the writer's compositions. The 60 per cent Sustained Performance Fund is distributed on the basis of a five-year average of performances of the writer's compositions. The purpose of Fund B is to prevent too sharp fluctuations in the writer's income in any given year and thereby assure him a certain stability of income. Another purpose served by this Fund is to preserve a more equal balance between writers whose compositions have been the subject of extensive "song-plugging" and may therefore have only a four- to six-month vogue, and those less well promoted songs that may have a more continuing popular appeal and acceptance. The Accumulated Earnings Fund of 20 per cent is distributed on the basis of the length of time the writer has been a member of ASCAP, multiplied by the rating which he has achieved in the Sustained Performance Fund. Ac-

52 Discussed at p. 316 supra. 
cordingly, while the older members of the Society stand to benefit from Fund C, they benefit only to the extent that their compositions have evinced sustained carrying power over the years ${ }^{53}$

6. Opportunity of Impartial Review. One of the objectives of ASCAP's internal reorganization under the $195^{\circ}$ Judgment was "to assure its members an opportunity to protect their rights therough fair and impartial hearings based on adequate information." Reference has already been made to the "open window" which members have now been given as to the basis of ASCAP's operations. The democratic reforms mentioned in connection with the choice of directors and nominating committees have also been extended in large measure to the Boards of Appeals, the membership organs that pass on the validity of publisher and writer classifications, respectively. (See Article XIV of the Articles of Association, Section 6C.) More important, however, is the establishment of a right of independent review; Section XIII(C) of the Judgment provides

that any member may appeal from the final determination of his classification by any ASCAP committee or board to an impartial arbiter or panel.

One surface indication of the effectiveness of the new procedures for the determination of writer revenue classifications is the fact that, while there were eleven appeals from such classifications in 1949 and thirteen in $195^{\circ}$, there was only one in I95I, one in 1952, and none in 1953. This seems noteworthy, especially since it seems agreed that the long overdue reform in the allocation of ASCAP writer revenues created an immediate hardship period for most ASCAP writers.

It may also be significant that the publishers have voluntarily shifted, since the I950 Judgment was entered, to a completely mathematical basis of revenue distribution. Prior to 1952,55 per cent of all publisher royalties had been allotted in exact mathematical relationship to the number of performances, 15 per cent on the basis of the length of time the works had been in the ASCAP repertory in relation to performances over the years, and 30 per cent on the basis of a subjective criterion of "availability." In 1952 , "availability" was given a mathematical content; it now refers to the five-year average of performance of those compositions that are more than two years old. While the publishers had five appeals from membership classifications in I95I, and six in I952, none were reported for the year I953.

7. Right of Individual Licensing. Section IV(B) of the Amended Consent Judgment gives an ASCAP member legal carte blanche to issue to users non-exclusive licenses for public performances. It prohibits ASCAP from

limiting, restricting, or interfering with the right of any member to issue to a user nonexclusive licenses for rights of public performance.

${ }^{53}$ There is an elaborate point rating system in connection with the Sustained Performance Fund, which serves as a cushion against either too rapid a rise, or too precipitous a decline, in earning power. Also, the Sustained Performance Fund has, since its inception in $595 \mathrm{I}$, been amended so that, with respect to half of that Fund, no writer will experience any loss of income until October, 1956; at the same time, the rise of members to higher income classifications has been accelerated. These are matters too intricate (and from a general antitrust standpoint too inconsequential) to be more than mentioned. 
The r94I Consent Decree had contained a provision which purported to prohibit ASCAP from acquiring or asserting any exclusive performance rights. However, this prohibition was completely nullified by language allowing ASCAP to impose five conditions on this right of individual licensing. ${ }^{64}$ The 1950 amended version strikes this limiting language.

While the Amended Consent Judgment vindicates an ASCAP member's rights to license performing rights even while a member of ASCAP, this legal vindication may well be meaningless economically. The fundamental premise underlying ASCAP's continued existence and acceptability to users was that ASCAP's users needed immediate access to ASCAP's entire range of compositions, and that it was impracticable for them to negotiate with individual writers and publishers. Nevertheless, should economic circumstances ever be propitious for the exercise of this right of individual licensing, its legal basis has been firmly established in the Amended Consent Judgment.

\section{EpILOGUE}

The considerations explored in this article would appear to be a long way from the simple command of Section 4 of the Sherman Act "to prevent and restrain" violations of the Act, and to have traversed a social, economic and administrative area that might superficially seem not to concern antitrust policy. But a complex industrial combination, exercising quasi-governmental powers of economic life and death over its members and controlling an entertainment package the legal form of which was basically crystallized forty years ago but the economic impact of which is still largely in flux and development, will call for more deft antitrust handling than a combination to fix the price of electric lamps.

When a complicated machine is taken back to the factory for overhauling and reconditioning, the repair crew does not discharge its functions by a few welldirected blows of a sledge hammer. The machine is dis-assembled into its hundreds of constitutent parts, which are examined, cleaned, lubricated, replaced, and sometimes rearranged. The performance tests that the re-assembled machine must satisfy may be of all kinds-mechanical, electrical, visual, electronic. Perhaps this analogy may explain why the judicial resolution of copyright-antitrust conflict should take the form of a complicated mosaic, consisting in large part of notions from the

\footnotetext{
54 Section II (I) of the I94I Decree contains a proviso which enables defendant ASCAP to regulate the activities of its members in the following five respects: "(a) By requiring all moneys derived from the issuance of licenses by the respective members of defendant to be paid by the licensce to defendant and distributed in the same manner as other revenues; (b) requiring of its members that notice be given the defendant of their intent to issue licenses before the issuance of same; (c) by prohibiting the members from issuing exclusive licenses to commercial users of music; (d) by requiring, as a condition precedent to the issuance of a license by an individual member of the Society, the approval and consent, to be obtained by the licensor, of the composer (s), author (s) and publisher subject to such reasonable regulations as may be adopted by the composer (s), author (s) and publisher for that purpose; (c) by prohibiting the members from granting or assigning to persons, firms, corporations or cnterprises, including Broadcast Music, Inc., the right to license or assign to others the right to perform publicly for profit the respective copyrighted musical compositions of which performance rights are owned or controlled by the respective members of the defendant Society."
} 
diverse fields of constitutional law, patents, and corporate ethics, but unified by the overriding demands of the business world and of common sense.

\section{APPENDIX}

\section{Paragraph II (3), (4) and (5) of ASCAP Consent Decree of March 4, x94I}

\section{(Relating to radio broadcasting)}

(3) Defendant, American Society of Composers, Authors and Publishers, shall not require, as a condition to any offer to license the public performance for profit of a musical composition or compositions for radio broadcasting, a license fee of which any part shall be (a) in respect of commercial programs, based upon a percentage of the income received by the broadcaster from programs in which no musical composition or compositions licensed by said defendant for performance shall be performed, or (b) in respect of sustaining programs, an amount which does not vary in proportion either to actual performances, during the term of the license, of the musical compositions licensed by said defendant for performance, or to the number of programs on which such compositions or any of them shall be performed; provided, however, that nothing herein contained shall prevent said defendant from licensing a radio broadcaster, on either or both of the foregoing basis, if desired by such broadcaster, or upon any other bases desired by such broadcaster.

With respect to any existing or future performing license agreement with a radio broadcaster, defendant, American Society of Composers, Authors and Publishers, shall not, if required by such broadcaster, refuse to offer a per program basis of compensation on either or both of the following bases which may be specified by the broadcaster:

(i) in respect of sustaining programs a per program license fee, expressed in terms of dollars, requiring the payment of a stipulated amount for each program in which musical compositions licensed by said defendant shall be performed;

(ii) in respect of commercial programs, a per program license fee, either expressed in terms of dollars, requiring the payment of a stipulated amount for each program in which the musical compositions licensed by said defendant for performance shall be performed, or, at the option of defendant, the payment of a percentage of the revenue derived by the licensee for the use of its broadcasting facilities in connection with such program.

In the event that defendant shall offer to license the public performance for profit of a musical composition or compositions for radio broadcasting upon either or both of the foregoing per program bases, and shall also offer to license such performance on a basis of compensation which shall not vary in direct proportion either to actual performances during the term of the licenses of the musical compositions licensed by said defendant for performance or to the number of programs on which musical compositions licensed by defendant shall be performed, defendant shall act in good 
faith so that there shall be a relationship between such per program basis and such other basis, justifiable by applicable business factors, including availability, so that there will be no frustration of the purpose of this sub-paragraph to afford radio broadcasters alternative basis of license compensation.

(4) Defendant, American Society of Composers, Authors and Publishers, shall not license the public performance for profit of any musical composition or compositions except on a basis whereby, in so far as network radio broadcasting is concerned, the issuance of a single license, authorizing and fixing a single license fee for such performance by network radio broadcasting, shall permit the simultaneous broadcasting of such performance by all stations on the network which shall broadcast such performance, without requiring separate licenses for such several stations for such performance.

(5) With respect to any musical composition in defendant's catalogue of musical compositions licensed for radio broadcasting and which is or shall be lawfully recorded for performance on specified commercially sponsored programs on an electrical transcription or on other specially prepared recordation intended for broadcasting purposes, said defendant shall not refuse to offer to license the public performance for profit by designated radio broadcasting stations of such compositions by a single license to any manufacturer, producer or distributor of such transcription or recordation or to any advertiser or advertising agency on whose behalf such transcription or recordation shall have been made who may request such license, which single license shall authorize the broadcasting of the recorded composition by means of such transcription or recordation by all radio stations enumerated by the licensee, on terms and conditions fixed by said defendant without requiring separate licenses for such enumerated stations. 